\title{
PERSEPSI PENGGUNA E-COMMERCE TERHADAP KUALITAS INFORMASI PEMBELIAN BARANG DENGAN METODE PEMBAYARAN CASH ON DELIVERY (COD) BERDAMPAK PADA TERJADINYA PENGANCAMAN KEPADA KURIR JASA EXPEDISI
}

\author{
Marshelia Gloria Narida \\ Program Studi Ilmu Komunikasi, Universitas Kristen Indonesia \\ E-mail: marshelia.gloria@uki.ac.id
}

\begin{abstract}
Purchasing goods with cash on delivery (COD) payment method is a service presented by Shopee to make it easier for buyers who don't have mobile or internet banking. The buyer pays for the goods when the goods have arrived at the delivery address delivered by the expedition service courier. However, some shoppers vented their disquire to the couriers of the expedition service when the goods they received did not match what they ordered through the Shopee app. Informants in the study suggested that their perception of the quality of information Shopee provides related to COD is still inaccurate, not yet timely, not yet relevant and incomplete. Shopee is considered to still focus on favorable information, not information that educates buyers related to COD. Information that is not received by the buyer can trigger disappointed buyers to vent to the courier expedisi service. Shopee is advised to create information in the form of interesting visualizations, not with long sentences so that it is easy to understand. Information is placed on the display menu that is easily seen by the buyer as on the main page or the information appears when the buyer will check out the item. Good information can prevent disappointed buyers from doing acidification or violence to couriers.
\end{abstract}

Keywords: Perception; Quality of Information; Cash on Delivery (COD)

\begin{abstract}
ABSTRAK
Pembelian barang dengan metode pembayaran cash on delivery (COD) merupakan sebuah layanan yang dihadirkan oleh Shopee untuk memudahkan pembeli yang tidak memiliki mobile atau internet banking. Pembeli membayar barang ketika barang tersebut telah tiba pada alamat pengiriman yang diantarkan oleh kurir jasa expedisi. Namun, beberapa pembeli melampiaskan kekecewaaannya kepada kurir jasa expedisi ketika barang yang mereka terima tidak sesuai dengan yang mereka pesan melalui aplikasi Shopee. Informan dalam penelitian ini mengemukakan bahwa persepsi mereka terhadap kualitas informasi yang diberikan Shopee terkait COD masih belum akurat, belum tepat waktu, belum relevan dan belum lengkap. Shopee dinilai masih berfokus kepada informasi yang menguntungkan, tidak kepada informasi yang mengedukasi pembeli terkait COD. Informasi yang tidak diterima oleh pembeli dapat menjadi penyebab dari marahnya pembeli kepada kurir jasa expedisi. Shopee disarankan membuat informasi terkait pembelian dengan metode pembayaran COD dalam bentuk visualisasi yang menarik, tidak dengan kalimat yang panjang sehingga mudah dimengerti. Informasi tersebut diletakkan pada menu tampilan yang mudah dilihat oleh pembeli seperti pada halaman layar utama atau informasi tersebut muncul ketika pembeli akan melakukan cek out atas barang dengan metode pembayaran COD tersebut. Hal tersebut dapat mencegah ketidakpahaman atau kebingungan pembeli yang berbelanja online melalui aplikasi Shopee dengan metode pembayaran COD.
\end{abstract}

Kata Kunci: Persepsi; Kualitas Informasi; Cash on Delivery (COD)

Submisi: 15 Agustus 2021 


\section{Pendahuluan}

E-commerce merupakan salah satu platform yang bergerak dalam bidang ekonomi digital, sebuah aktivitas ekonomi yang memanfaatkan bantuan teknologi informasi dan komunikasi. Dalam pengembangan bisnisnya, e-commerce terus berfokus pada upaya menjangkau publik di seluruh Indonesia dari berbagai latar belakang geografis, ekonomi, pendidikan dan budaya yang berbeda. Salah satu pengembangan yang dilakukan adalah dengan menghadirkan Cash On Delivery (COD), yaitu metode pembayaran atas pembelian barang yang dilakukan ketika barang tersebut tiba di alamat tujuan atau alamat pengiriman. Metode pembayaran ini tentunya mempermudah bagi customer yang tidak memiliki layanan internet banking maupun mobile banking serta juga dapat digunakan bagi customer yang ragu membayar barang sebelum melihat barang tersebut tiba di alamat pengiriman.

Pada awalnya, COD merupakan transaksi jual beli dengan cara penjual dan pembeli bertemu di sebuah tempat dan waktu yang telah disepakati (money.kompas.com, 16 Februari 2021). Namun, COD yang dijalankan dalam transaksi jual beli melalui platform $e$ commerce saat ini mengalami perubahan bentuk, yaitu pembeli dapat melakukan pembelian barang melalui aplikasi $e$ commerce dengan melakukan pembayaran ketika barang tersebut sudah diterima pembeli. Barang yang diterima pembeli tersebut merupakan barang yang ia pesan dan kemudian dikirimkan oleh penjual menggunakan jasa expedisi dan ketika pembeli menerima barang tersebut maka pembeli memberikan uang sejumlah nominal atas ongkos kirim dan barang yang ia beli.

Salah satu e-commerce yang menyediakan pembelian barang menggunakan metode pembayaran COD adalah Shopee yang mengemukakan bahwa COD merupakan metode pembayaran yang dilakukan secara langsung di tempat setelah pesanan dari kurir diterima oleh Pembeli (help.shopee.co.id, 24 Desember 2019). Jika berbelanja melalui aplikasi e-commerce dengan metode pembayaran COD, pembeli harus memahami terlebih dahulu terkait aturan yang diberlakukan oleh e-commerce. Aturan dalam pembelian barang menggunakan metode pembayaran COD yang diterapkan Shopee, pembeli harus harus melakukan pembayaran kepada kurir sebelum menerima/membuka paket dan pembeli yang melakukan penolakan pembayaran atau tidak ada di tempat saat kurir mengirim paket $2 \mathrm{x}$ dalam 60 hari akan diblokir dari sistem pembayaran COD. Informasi terkait aturan belanja online melalui aplikasi Shopee dengan menggunakan metode pembayaran COD terdapat dalam menu pusat bantuan pada aplikasi Shopee (masuk aplikasi Shopee, klik menu saya yang terletak di pojok kanan bawah, lalu klik menu pusat bantuan dan ketikkan COD pada kolom cari topik) maka akan muncul informasi seperti pada gambar di bawah ini :

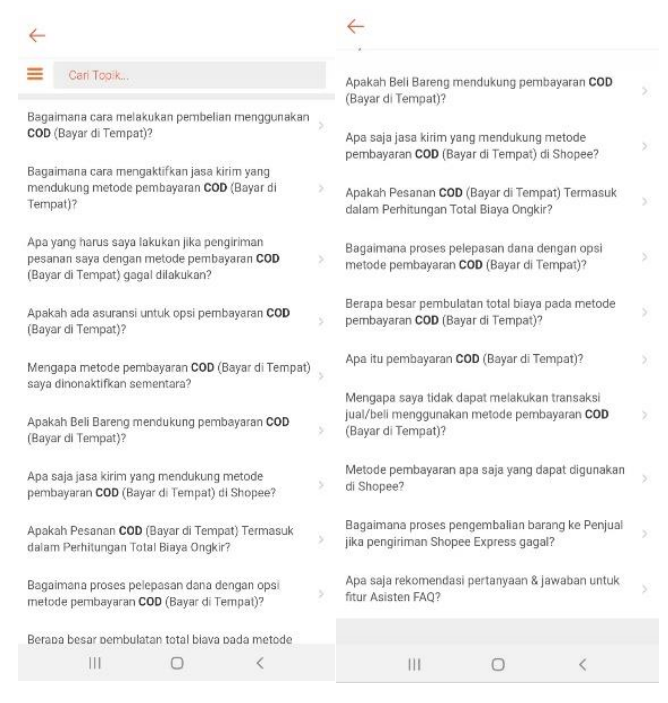

Gambar 1. Informasi terkait aturan belanja online melalui aplikasi Shopee yang tertera dalam aplikasi Shopee

Hasil riset Badan Pusat Statistik yang di publish oleh katadata.id sebanyak $73,04 \%$ pembayaran melalui e-commerce dilakukan oleh pembeli dengan layanan COD pada tahun 2019 (id.techinasia.com, 19 Januari 2021). Data tersebut menunjukkan antusiasme yang besar dari 
pengguna $e$-commerce untuk menggunakan metode pembayaran COD dalam transaksi belanja online. Namun, di tengah besarnya antusiasme tersebut, muncul sebuah permasalahan yang terjadi pada saat proses penerimaan barang dari kurir jasa expedisi kepada penerima barang.

Seorang pria di Ciputat melakukan pengancaman menggunakan pedang kepada kurir jasa expedisi ketika mengantarkan barang yang ia beli melalui aplikasi $e$ commerce dengan metode pembayaran COD pada 25 Mei 2021. Hal tersebut ia lakukan karena pria tersebut merasa ditipu karena paket yang seharusnya ia terima seharusnya berisi barang yang ia beli, namun setelah membayarkan sejumlah nominal barang, ia mendapati bahwa paket yang ia terima hanya berupa kardus kosong. Pria tersebut kemudian meminta kurir jasa expedisi untuk mengembalikan uang yang telah ia bayar sambil mengancam kurir tersebut dengan pedang (Megapolitan. Kompas.com, 26 Mei 2021).

Pengancaman menggunakan senjata kepada kurir expedisi juga terjadi di Desa Gunung Mulya, Kecamatan Tenjolaya, Kabupaten Bogor. Seorang pria menodongkan pistol kepada kurir jasa expedisi yang mengantarkan barang dengan metode pembayaran COD. Penodongan pistol tersebut dilakukan karenakan pria tersebut merasa barang berupa sandal yang ia terima tidak sesuai dengan ukuran sandal yang ia pesan. Ia marah dengan kurir dikarenakan kurir tetap meminta pria tersebut untuk membayar atas paket barang yang telah ia buka (kompas.com, 4 Mei 2021)

Selain ancaman menggunakan senjata tajam, kurir jasa expedisi yang mengantar barang pesanan dari belanja online menggunakan dengan metode pembayaran COD juga mendapatkan pelecehan secara verbal. Bersumber dari Kompas.tv.com (16 Mei 2021), seorang wanita merasa kecewa karena barang yang diterima tidak sesuai dengan barang yang ia pesan melalui aplikasi e-commerce. Hal tersebut membuat ia tidak mau membayar barang tersebut kepada kurir jasa ekspedisi. Namun, kurir ekspedisi tetap meminta bayaran atas barang tersebut dikarenakan paket telah dibuka. Wanita tersebut mengucapkan kata-kata kasar berupa makian dan melemparkan isi paket tersebut kepada kurir.

Bersumber dari kompas.com (11 Juni 2021), seorang kurir jasa expedisi disiram air dan mendapat kata-kata kasar ketika mengantarkan barang dengan metode pembayaran COD. Kejadian ini tidak jauh berbeda dengan tiga kejadian yang telah peneliti jabarkan dalam paragraf-paragraf sebelumnya, yaitu pembeli merasa kecewa karena barang yang ia terima tidak sesuai dengan yang ia pesan melalui aplikasi $e$ commerce. Pembeli menolak untuk membayar barang tersebut kepada kurir jasa expedisi.

Dari keempat kejadian tersebut, peneliti melihat bahwa masih terdapat beberapa pengguna e-commerce yang melakukan pembelian dengan metode pembayaran COD tidak memahami tentang aturan dalam metode pembayaran COD yang diberlakukan. Asumsi dalam penelitian ini, aturan dalam metode pembayaran COD yang mengharuskan pembeli untuk membayar atas barang yang telah dibuka ketika paket diterima pada alamat tujuan, tata cara penolakan terhadap paket yang telah dibeli dan cara pengajuan pengembalian barang masih belum dipahami sehingga beberapa pembeli melampiaskan kekecewaannya kepada kurir jasa expedisi ketika barang yang ia terima tidak sesuai dengan yang mereka pesan. Hal ini menunjukkan adanya informasi dari $e$ commerce yang tidak dipahami oleh pembeli.

Berdasarkan apa yang telah peneliti jabarkan pada paragraf-paragraf sebelumnya, penelitian ini dilakukan untuk menjawab pertanyaan bagaimana persepsi pengguna e-commerce terhadap kualitas informasi yang diberikan Shopee terkait aturan dalam pembelian barang menggunakan metode pembayaran COD? apakah persepsi tersebut dapat berpotensi 
menimbulkan pengancaman kepada kurir jasa expedisi? Kedua jawaban atas pertanyaan tersebut akan peneliti dapatkan melalui wawancara dengan informan dalam penelitian ini.

Adapun tujuan penelitian ini adalah ingin mengetahui persepsi pengguna $e$ commerce terhadap kualitas informasi yang diberikan Shopee terkait aturan dalam pembelian barang menggunakan metode pembayaran COD dan mengetahui apakah persepsi tersebut dapat berpotensi menimbulkan pengancaman kepada kurir jasa expedisi. Manfaat akademis dari penelitian ini diharapkan dapat menjadi penelitian terdahulu bagi peneliti selanjutnya yang ingin meneliti permasalahan publik dari sebuah $e$ commerce terkait kualitas informasi yang merupakan salah satu tolak ukur dari berhasil atau tidaknya komunikasi yang dijalin perusahaan dengan publiknya. Penelitian ini diharapkan memberi manfaat sosial bagi masyarakat khususnya pengguna e-commerce agar dapat menelusuri segala informasi yang terdapat dalam aplikasi $e$ commerce sehingga tidak terjadi ketidakpahaman terhadap aturan dalam layanan yang diterapkan oleh e-commerce yang mereka gunakan. Melalui penelitian diharapkan juga bermanfaat bagi Shopee untuk mendapatkan gambaran tentang persepsi publik dari informasi yang telah disampaikan melalui aplikasi, sehingga dapat menjadi bahan evaluasi untuk mencegah terjadinya pengancaman terhadap kurir jasa expedisi yang dilakukan oleh pembeli.

\section{Persepsi}

Persepsi ditinjau dari ilmu komunikasi merupakan pengalaman dari objek, peristiwa maupun hubunganhubungan yang diperoleh dengan cara menyimpulkan informasi dan menafsirkan pesan. Rakhmat (2005:50) mengemukakan bahwa persepsi merupakan sebuah hubungan yang diperoleh melalui cara menyimpulkan informasi dan menafsirkan pesan. Sejalan dengan apa yang dikemukakan Rakhmat tersebut, Mulyana (2015:180) mengutarakan bahwa persepsi merupakan inti dari komunikasi, sedangkan penafsiran (interpretasi) merupakan inti persepsi yang identik dengan penyandianbalik (decoding) dalam proses komunikasi.

Prinsip persepsi yang penulis rangkum dari Mulyana (2015:191-207), yaitu persepsi berdasarkan pengalaman (persepsi manusia terhadap seseorang, objek, atau kejadian dan reaksi berdasarkan pengalaman), persepsi bersifat selektif (setiap manusia sering mendapatkan rangsangan yang bersifat inderawi), persepsi bersifat dugaan (terjadi karena data yang diperoleh mengenai objek ridak lengkap sehingga membuat kita menafsirkan objek dengan makna yang lebih lengkap), persepsi bersifat kontekstual (ketika kita melihat seseorang, suatu objek atau suatu kejadian, konteks rangsangan tersebut memengaruhi kita untuk memiliki persepsi yang sama).

\section{Informasi}

Informasi merupakan bagian dari komunikasi. Dalam berkomunikasi melalui tatap muka maupun melalui media baru seperti media sosial maupun komunikasi yang berlangsung melalui aplikasi $e$ commerce, kebutuhan akan informasi menjadi komponen penting yang menjadikan alasan seseorang berkomunikasi dengan orang lain. Menurut Berelson \& Stainer, komunikasi adalah suatu proses penyampaian informasi, gagasan, emosi, keahlian dan lain-lain melalui penggunaan simbol-simbol seperti kata-kata, gambargambar, angka-angka dan lain-lain (Haryanto dan Juniari, 2019:18).

Pada komunikasi yang dilakukan melalui aplikasi e-commerce, komunikasi tidak hanya terjalin antara penjual dan pembeli, namun juga antara pihak $e$ commerce dengan penjual serta pembeli. Komunikasi yang berlangsung antara pihak e-commerce dengan pembeli dilakukan melalui fitur chat yang terdapat dalam aplikasi maupun pada berbagai menu dalam aplikasi yang memuat informasi terkait 
transaksi pembelian online. Tidak jarang, komunikasi yang bermuatan informasi ini dilakukan oleh pihak e-commerce dengan bantuan Artificial Intelligence (AI).

Jogiyanto (2005:8) mengutarakan bahwa informasi merupakan suatu data yang diolah menjadi bentuk yang memiliki kegunaan bagi pihak yang menerima informasi tersebut. Berdasarkan pendapat tersebut, dapat diperoleh gambaran bahwa informasi yang kita sampaikan kepada orang lain merupakan hasil pengolahan atas data yang kita rekam dalam otak, kemudian kita sampaikan kepada orang lain. Setiap informasi memiliki kualitas yang berbeda tergantung bagaimana proses penyampaian, media yang digunakan, siapa penerima informasi, waktu pengiriman dan penerimaan informasi, gangguan dan lainnya. Kualitas dari informasi yang disampaikan dapat mempengaruhi persepsi dan respons orang yang menerima informasi tersebut.

Kualitas informasi merupakan
tingkat dimana informasi memiliki karakteristik seperti isi, bentuk, dan waktu yang memberikan nilai bagi para pengguna atau penerima informasi (O'Brien 2005:703). Dirangkum dari Susanto (2004:10) informasi dapat dikatakan berkualitas jika memiliki ciri-ciri:

1) Akurat. Informasi tidak bisa atau menyesatkan. Informasi harus akurat karena jika terdapat gangguang dapat mengubah atau bahkan merusak informasi yang ingin disampaikan oleh pengirim informasi.

2) Tepat pada waktunya. Informasi tidak boleh diterima terlambat karena dapat berpengaruh kepada proses pengambilan suatu keputusan penting.

3) Relevan. Informasi mempunyai manfaat untuk pengguna informasi.

4) Lengkap. Informasi yang diberikan harus dapat diterima lengkap oleh pengguna.

Berdasarkan apa yang telah peneliti jabarkan di atas, maka dapat disimpulkan bahwa suatu kualitas informasi harus akurat, tepat waktu, relevan, dan lengkap agar informasi yang ingin disampaikan pengirim informasi dapat diterima dan berguna untuk penerima informasi.

\section{Konseptualisasi Penelitian}

Sebagai acuan dalam penelitian, digunakan paradigma konstruktivisme, hal ini dikarenakan peneliti ingin mempelajari realitas sosial dengan melihat keadaan yang sebenarnya. Mulyana (2006:32) telah mengemukakan bahwa paradigma konstruktivisme memandang ilmu sosial harus berupa menjelaskan perilaku manusia sehingga dapat dipahami. Adapun pendekatan penelitian yang digunakan adalah pendekatan kualitatif, yaitu metode analisis yang digunakan untuk memberikan data penelitian sosial tanpa mengubah ke dalam format numerik (Barbie, 2012:403).

Untuk menjawab pertanyaan daam penelitian ini digunakan wawancara terencana tidak terstruktur kepada informan. Proses analisis data dalam penelitian ini sesuai dengan yang dikemukakan Yusuf (2014:401) yaitu pengumpulan data, reduksi data, penyajian data. Dalam memilih informan, peneliti menggunakan teknik purposive sampling yaitu penentuan sumber informasi berdasarkan pertimbangan tertentu (Yusuf 2014:368). Informan dalam penelitian ini berjumlah 4 orang, dengan kriteria informan adalah merupakan pengguna aplikasi Shopee, pernah berbelanja melalui aplikasi Shopee menggunakan metode pembayaran COD dalam tiga bulan terakhir (Mei, juni dan Juli 2021) minimal sebanyak 3 kali, pernah mengalami masalah dalam transaksi belanja online melalui metode pembayaran COD dan berdomisili di Jakarta Timur, DKI Jakarta.

Informan pertama yang selanjutnya akan diberi kode IU 1 bernama Wahyu Anita, merupakan seorang Ibu Rumah Tangga berdomisili di Bambu Apus, Jakarta Timur yang berbelanja melalui aplikasi Shopee sebanyak 4 kali dengan metode pembayaran metode pembayaran COD selama bulan mei, 
juni dan juli 2021. Alasan informan menggunakan metode pembayaran COD adalah karena informan kurang tanggap terhadap teknologi sehingga tidak memiliki mobile banking. Informan pernah menerima barang yang tidak sesuai dengan yang dipesan pada aplikasi Shopee.

Setelah informan pertama, akan diwawancarai informan kedua yang selanjutnya akan diberi kode IU 2 bernama Renato Yosia. Merupakan seorang mahasiswa perguruan tinggi swasta di Jakarta berusia 20 tahun. Informan merupakan pengguna tiga aplikasi $e$ commerce, namun e-commerce yang paling sering digunakan untuk berbelanja adalah Shopee. IU 2 telah berbelanja sebanyak 5 kali selama bulan mei, juni dan juli 2021 pada aplikasi Shopee menggunakan metode pembayaran COD. Permasalahan terkait metode pembayaran COD yang pernah dialami informan adalah waktu tiba kurir tidak sesuai dengan informasi pada aplikasi sehingga kurir tiba tengah malah saat informan sedang beristirahat. IU 2 menggunakan metode pembayaran COD karena tidak perlu ke atm dan susah jika harus ke atm setor tunai untuk mengisi saldo rekening maupun Shopeepay.

Informan ketiga bernama Anna adalah seorang mahasiswa SMA di DKI Jakarta dan berdomisili di Jakarta Timur yang telah melakukan belanja online melalui aplikasi Shopee dengan metode pembayaran COD sebanyak 3 kali selama bulan mei, juni dan juli 2021. Selanjutnya informan ketiga akan diberi kode IU 3. Informan pernah mengalami masalah dalam transaksi belanja online menggunakan metode pembayaran metode pembayaran COD yaitu barang yang diterima dalam keadaan rusak. COD menjadi metode pembayaran yang dipilih informan karena ia tidak memiliki mobile banking dan terkadang barang yang ingin dibeli sedang flash sale ketika IU 3 belum memiliki uang dan karena pembayaran dengan metode pembayaran COD menyediakan layanan untuk ia dapat melakukan cek out barang dan dibayarkan saat barang tiba sehingga masih ada waktu bagi IU 3 mencari uang untuk membayar barang yang telah dipesan.

IU 4 adalah kode informan keempat yang merupakan seorang petugas keamanan salah satu perumahan di wilayah Jakarta Timur bernama Namri Bin Rohman. Selama bulan Mei, Juni dan Juli 2021 IU 4 telah melakukan transaksi belanja online menggunakan metode pembayaran COD sebanyak 5 kali pada bulan mei, juni dan juli 2021. Informan pernah mengalami masalah yaitu barang yang diterima tidak sesuai dengan deskripsi barang yang tertera pada aplikasi Shopee. Metode pembayaran COD dipilih oleh informan karena IU 4 tidak memiliki mobile banking dan enggan untuk membuat mobile banking karena proses mengurusnya cukup rumit.

\section{Hasil Penelitian}

Berdasarkan hasil wawancara, IU 1 mengemukakan bahwa ia mengetahui adanya metode pembayaran COD dalam aplikasi Shopee dari kerabatnya, ia tidak mengetahui bahwa ada aturan terkait metode pembayaran COD dalam aplikasi Shopee. Menurut keterangan informan, ia juga tidak pernah mendapatkan informasi dari penjual maupun customer service Shopee terkait diperbolehkannya menolak paket sebelum paket tersebut dibuka. Selama pengalaman berbelanja online melalui Shopee pada bulan mei, juni dan juli dengan metode pembayaran COD, ia pernah 1 kali merasa barang yang dikirim adalah barang yang tidak sesuai dengan yang ia pesan. IU 1 memesan emergency lamp (lampu yang menyala saat listrik padam), namun yang ia terima adalah lampu LED yang bukan emergency lamp.

Namun, IU 1 tidak melakukan pengembalian barang karena pasrah dan berpikir prosedur pengembalian barang pasti ribet sehingga ia tidak mau mengajukan pengembalian barang. IU 1 mengemukakan bahwa ia mengetahui bahwa jika barang sudah dibuka, jika tidak sesuai dapat dikembalikan melalui aplikasi Shopee dari iklan yang ditayangkan Shopee menggunakan Artis yaitu Tukul Arwana. 
Namun, IU 1 menilai proses pengembalian dengan cara mengajukan pengembalian barang melalui aplikasi Shopee terlalu banyak tahapan sehingga informan enggan mempelajari prosedur pengembalian barang.

IU 1 juga memberikan keterangan bahwa ia tidak mengetahui di mana letak menu informasi terkait metode pembayaran COD ada pada menu dalam aplikasi Shopee sehingga ia merasa informasi yang disampaikan Shopee terkait metode pembayaran COD melalui aplikasi Shopee tidak akurat. Menurut IU 1 minimnya informasi ini dapat menjadi pemicu kekerasan yang dilakukan oleh beberapa pembeli terhadap kurir, karena pembeli tidak memahami informasi terkait metode pembayaran COD khususnya cara pengembalian barang.

Apa yang dikemukakan oleh UI 1, diutarakan juga oleh IU 3 dan IU 4 . IU 3 juga tidak mengetahui apakah ada atau tidak informasi detail terkait aturan metode pembayaran COD yang pernah dibagikan oleh Shopee khususnya melalui aplikasi Shopee. IU 3 memberi keterangan bahwa ia selama ini mengetahui tentang COD dan aturan COD dari informasi teman ataupun informasi dari media sosial milik berbagai akun yang ia temukan (bukan akun official Shopee). Pada saat proses wawancara, peneliti memberikan informasi bahwa informasi terkait metode pembayaran COD terdapat pada aplikasi Shopee pada menu pusat bantuan yang kemudian informan dapat mengetik kata kunci yaitu COD pada kolom Cari Topik. IU 3 mengungkapkan bahwa ia baru tahu bahwa ada informasi terkait COD pada menu pusat bantuan dari apa yang disampaikan oleh peneliti. Menurut IU 3, letak informasi pada menu pusat bantuan tidak memudahkan pengguna untuk mendapatkan informasi terkait metode pembayaran COD. Hal tersebut dikarena sangat jarang pengguna yang rajin memperhatikan seluruh menu yang terdapat dalam aplikasi Shopee ditambah menu tersebut tidak tertera pada halaman utama yang mudah ditemukan.
Sama dengan apa yang diutarakan oleh IU 1, pengancaman dan kata kasar yang diterima oleh kurir jasa expedisi bisa saja terjadi jika pembeli merasa tidak mendapatkan informasi terkait metode pembayaran COD yang jelas dari Shopee sehingga kurir menjadi pelampiasan kekecewan. Hal tersebut pernah dialami oleh IU 3, ketika barang yang ia terima berupa face shield rusak, ia langsung mengirimkan pertanyaan melalui aplikasi whatsapp kepada kurir jasa expedisi yang mengantarkan paketnya. Namun kurir jasa expedisi mengarahkan informan untuk mengajukan pengembalian barang melalui aplikasi Shopee. Informan yang merasa kurang puas dengan jawaban tersebut langsung menuduh kurir jasa expedisi tidak bertanggung jawab karena telah membuat paketnya rusak. Kekesalan informan semakin bertambah ketika mengajukan pembelian barang melalui aplikasi Shopee diminta bukti berupa video unboxing (video yang dibuat saat membuka paket) sementara informan tidak mengetahui bahwa ketika membuka paket agar dapat melakukan pengembalian barang harus disertakan bukti berupa video unboxing.

IU 4 juga memberikan keterangan yang sama bahwa ia juga tidak mengetahui bahwa ada informasi pada aplikasi Shopee terkait aturan dalam pembelian barang menggunakan metode pembayaran COD dikarenakan ia mendapatkan informasi yang berbeda-beda dari jasa kurir expedisi terkait aturan yang berlaku dalam pembelian melalui aplikasi Shopee menggunakan metode pembayaran COD. IU 4 mengutarakan bahwa ada 1 kurir jasa expedisi yang memperbolehkan ia untuk membuka paket terlebih dahulu baru melakukan pembayaran, sedangkan jasa kurir expedisi lainnya meminta ia melakukan pembayaran terlebih dahulu baru boleh membuka paket. Perbedaan informasi dari kurir jasa expedisi tersebut menghasilkan kebingungan bagi informan.

Kebingungan informasi karena tidak adanya informasi jelas dari Shopee tentang prosedur pengembalian barang menurut 
informan dapat menjadi penyebab sebagian orang melakukan protes kepada kurir jika barangnya kurang sesuai dengan apa yang diharapkan. IU 4 sendiri pernah mengalami kekecewaan akibat baju koko yang ia pesan tidak sesuai dengan ukuran yang ia pilih pada variasi barang. Informan memilih ukuran L sedangkan yang datang adalah baju koko berukuran XL. Untuk mengajukan pengembalian barang, IU 4 meminta bantuan anaknya untuk mengajukan pengembalian barang kepada penjual melalui aplikasi Shopee. Namun, IU 4 berkeputusan untuk membatalkan pengajuan pengembalian barang karena dalam proses pengembalian barang ternyata ongkos kirim untuk pengembalian barang dibebankan kepada informan karena penjual tidak mau menanggung ongkos kirim. IU 4 mengungkapkan hal-hal seperti ini yang mungkin saja memicu pembeli dengan metode pembayaran COD di Shopee dapat melampiaskan kekesalan tersebut kepada kurir.

Berbeda dengan IU1, IU 3 dan IU 4, peneliti menemukan bahwa IU 2 memiliki persepsi bahwa informasi yang disampaikan Shopee terkait aturan dalam metode pembayaran COD sudah akurat. IU 2 mengetahui tentang informasi terkait metode pembayaran COD dalam menu pusat bantuan pada aplikasi Shopee, ia menuturkan bahwa Shopee sudah memberikan deskripsi jelas tentang aturanaturan yang berlaku dalam metode pembayaran COD melalui aplikasi Shopee. IU 2 sudah sangat memahami aturan dalam metode pembayaran COD karena IU 2 sudah pernah menggunakan metode pembayaran COD melalui aplikasi e-commerce lainnya dan pertama kali mengenal metode pembayaran COD sejak COD masih berbentuk pertemuan antara pembeli dan penjual disuatu tempat untuk melihat langsung barang yang ditawarkan penjual.

Menurut persepsi IU 2 masih adanya pembeli yang melampiaskan kekesalan kepada kurir jasa expedisi karena barang yang diterima tidak sesuai, hal tersebut disebabkan karena pembeli tersebut tidak tanggap terhadap teknologi dan masih baru mencoba tentang metode pembayaran COD. Menurut IU 2, rendahnya literasi membuat pembeli kurang memahami informasi yang disampaikan oleh Shopee. Namun, informan juga berpendapat bahwa Shopee harus lebih tanggap lagi terhadap pengguna yang memiliki literasi rendah, sebagai salah satu bagian dari publik Shopee yang beragam.

Berdasarkan ketepatan waktu, IU 1 dan IU 4 sama-sama berpendapat bahwa Shopee memberikan ketepatan waktu terkait informasi tentang kedatangan kurir yang akan mengantarkan barang dengan metode pembayaran COD, sehingga informan dapat mempersiapkan uang tunai. Informasi tersebut muncul dalam menu "dikirim" yang menunjukkan status pengiriman serta lokasi keberadaan paket. Namun, hal tersebut berbeda dengan IU 2 dan IU 3 yang justru berpendapat bahwa Shopee tidak akurat dalam memberikan informasi terkait kapan waktu kedatangan kurir, sehingga waktu kedatangan kurir sering berbeda dengan waktu keterangan pada aplikasi Shopee sehingga kurir datang pada saat informan sedang beristirahat, tidak ada di rumah atau informan sedang tidak memiliki uang tunai.

Menurut IU 2, informasi yang disampaikan Shopee terkait metode pembayaran COD pada aplikasinya sudah sangat relevan, berguna untuk setiap pengguna $e$-commerce yang lebih menyukai pembayaran belanja online melalui metode pembayaran COD. Namun, masukan dari informan adalah informasi yang diberikan Shopee terkait metode pembayaran COD cenderung terlihat lebih kepada pemasaran dibanding dengan edukasi kepada pembeli. Menurut IU 2, edukasi penting mengingat beragamnya publik yang menggunakan metode pembayaran COD dalam transaksi belanja online melalui aplikasi Shopee.

Namun, apa yang dikemukakan IU 2 berbeda dengan IU 1, IU 3 dan IU 4. IU 1 mengungkapkan bahwa Shopee tidak pernah memberikan informasi apapun terkait dengan metode pembayaran COD. Hal tersebut sama dengan apa yang dikemukakan oleh IU 3, informan 
berpendapat bahwa Shopee lebih banyak promosi dibanding memberikan informasi terkait metode pembayaran COD. Shopee lebih menginformasikan terkait bebas ongkir jika menggunakan metode pembayaran COD dibanding informasi tentang tata cara pengembalian barang dan keharusan membuat video unboxing agar dapat menjadi bukti ketika mengajukan pengembalian barang. IU 3 memiliki pengalaman ingin mengajukan pembelian barang karena barang yang ia terima rusak, namun penjual meminta video unboxing karena hal tersebut merupakan syarat ketika mengajukan pengembalian barang melalui aplikasi Shopee. Permintaan untuk upload video unboxing tersebut juga ditemukan pembeli ketika ia mengajukan pengembalian barang melalui pusat resolusi Shopee. IU 3 merasa kecewa karena tidak adanya informasi tersebut dalam aplikasi Shopee sebelum ia melakukan cek out barang dan menggunakan metode pembayaran COD. Hal tersebut menunjukkan bahwa IU 1, IU 3 dan IU 4 memiliki persepsi bahwa informasi yang disampaikan Shopee terkait metode pembayaran COD tidak relevan sehingga dapat saja membuat pembeli yang tidak mengetahui informasi secara jelas, akan meminta kurir untuk bertanggung jawab sebagai pihak yang terlihat dalam transaksi belanja online. IU 4 memberikan jawaban bahwa ia tidak terlalu memusingkan tentang informasi yang diberikan oleh Shopee terkait metode pembayaran COD relevan atau tidak. IU 4 berpendapat bahwa pada dasarnya seluruh aplikasi hanya mementingkan keuntungan untuk bisnisnya sehingga tidak mungkin aplikasi dapat memberikan informasi yang jujur terkait aturan dalam layanan yang disediakan, dalam hal ini layanan metode pembayaran COD.

Pada dimensi terakhir dari kualitas informasi, peneliti menemukan bahwa IU 1, IU 2, IU 3 dan IU 4 berpendapat bahwa informasi yang diberikan Shopee melalui aplikasinya terkait metode pembayaran COD tidak lengkap. Menurut IU 1, Shopee tidak memberikan informasi secara lengkap dan aktif dalam berupaya memberikan informasi. Menurut IU 2, penjelasan aturan metode pembayaran COD yang ada pada menu pusat bantuan menyulitkan pengguna Shopee yang tidak memiliki waktu untuk membuka seluruh menu Shopee ditambah beragamnya publik Shopee dari berbagai latar belakang pendidikan, seharusnya Shopee lebih membuat informasi pada tempat yang mudah ditemukan oleh berbagai pengguna aplikasi Shopee. IU 3 berpendapat bahwa informasi yang disampaikan Shopee tidak lengkap, lebih lengkap informasi yang diberikan teman atau akun media sosial selain Shopee terkait metode pembayaran COD pada aplikasi Shopee. Apa yang diungkapkan oleh IU 3 juga dikemukakan oleh IU 4 karena informan juga merasa bahwa informasi dari kurir jasa expedisi atau orang sekitar lebih banyak dibanding informasi yang diberikan Shopee. IU 4 mengungkapkan bahwa informasi yang didapat dari orang lain selain aplikasi Shopee terkadang bisa saja salah dan menimbulkan bahwa orang justru berpikir kurir jasa expedisi adalah penyebab tidak sesuainya barang yang diterima, sehingga Shopee seharusnya dapat menghadirkan informasi yang lebih lengkap dan mudah dijangkau untuk mendapatkan informasi tersebut.

Terkait beberapa kasus pengancaman dengan senjata tajam, pelecehan verbal dan perlakuan kasar yang diterima oleh kurir jasa expedisi, IU 1 memiliki persepsi minimnya informasi yang diberikan oleh Shopee sendiri terkait metode pembayaran COD secara keseluruhan seperti prosedur pengembalian barang dapat membuat pembeli bingung dan melampiaskan rasa kecewa atas barang yang ia terima kepada kurir. Pembeli yang kecewa dapat saja melampiaskan amarahnya kepada kurir karena kurir adalah orang yang ditemui langsung, kurir sebagai orang yang berinteraksi langsung dapat dianggap sebagai pihak yang tepat dipersalahkan. Tidak akuratnya informasi, tidak tepat waktunya informasi, tidak 
relevannya informasi dan tidak lengkapnya informasi yang disampaikan oleh Shopee melalui aplikasinya terkait metode pembayaran COD menjadi penyebab dari banyaknya kesalahpahaman pembeli tentang aturan dalam metode pembayaran COD. IU 1 menyarankan Shopee lebih aktif dalam memberikan informasi tidak hanya tentang metode pembayaran COD namun lebih aktif lagi memberikan informasi detail tentang prosedur pengembalian barang karena tidak semua pembeli rajin untuk melakukan chat dengan customer service.

IU 2 memiliki persepsi bahwa kejadian pengancaman terhadap kurir menunjukkan bahwa masih rendahnya minat membaca, sehingga Shopee sebaiknya tidak membuat informasi dengan menggunakan kalimat-kalimat panjang melainkan dengan kalimat ringkas atau ditambahkan visualisasi menarik sehingga mudah dimengerti oleh berbagai pengguna dari berbagai latar belakang untuk menghindari ketidakmampuan beberapa pengguna Shopee untuk menangkap informasi yang disampaikan. Hal tersebut untuk meminimalisir informasi yang tidak tersampaikan, sehingga tidak menimbulkan peluang terjadi pengancaman kepaa kurir expedisi.

Informasi yang kurang aktif dan kurang gencar disampaikan oleh Shopee, dapat berpotensi munculnya pelampiasan amarah kepada kurir, hal tersebut diungkapkan oleh IU 3. Bisa saja pembeli saat itu sedang mengalami permasalahan pribadi lalu kekecewaan terhadap barang yang diterima membuat ia tidak mampu membendung emosi sehingga melampiaskan kepada kurir. Disamping itu, lemahnya kesadaran membaca yang masih lemah juga sangat berpengaruh. IU 3 berharap Shopee lebih membuat informasi terkait metode pembayaran COD yang mudah dijangkau oleh pembeli, mengingat masih banyak pembeli yang malas membaca, misalkan informasi terkait metode pembayaran COD dibuat di halaman utama atau saat melakukan cek out barang. IU 4 juga menambahkan bahwa bentuk pengancaman dan pelecehan verbal yang diterima kurir jasa expedisi bukanlah sesuatu hal yang dapat dianggap remeh, Shopee dapat mencegah hal itu terjadi dengan cara memberikan informasi pada menu aplikasi yang mudah ditemui oleh pengguna seperti pemberitahuan itu muncul ketika pembeli akan melakukan pembelian barang atau Shopee menghimbau penjual untuk membantu memberikan informasi terkait cara pembayaran, pengembalian barang atau penolakan barang yang dapat dilakukan dalam pembelian melalui metode pembayaran COD.

\section{Analisis dan Interpretasi}

Pada bagian ini peneliti akan memaparkan hasil temuan dalam penelitian ini dalam bentuk tabel agar mudah dipahami.

Tabel 1. Temuan Data

\section{Kualitas Informasi}

Akurat

\section{Persepsi}

Tiga informan memiliki persepsi bahwa Shopee belum menyampaikan informasi yang akurat terkait metode pembayaran COD seperti aturan larangan untuk tidak membuka barang sebelum bayar, prosedur pengembalian barang, ongkos kirim atas pengembalian barang dan keharusan membuat video unboxing untuk mengajukan pengembalian barang. Ketiga informan tidak mengetahui bahwa ada informasi terkait halhal tersebut pada menu pusat bantuan yang tertera pada aplikasi Shopee. Satu informan memiliki persepsi bahwa Shopee telah memberikan informasi yang akurat, namun namun rendahnya literasi pada sebagian pembeli membuat mereka kurang memahami informasi yang disampaikan oleh Shopee. Shopee harus lebih tanggap lagi terhadap pengguna yang 
memiliki literasi rendah, sebagai salah satu bagian dari publik Shopee yang beragam. Tidak akuratnya informasi yang disampaikan oleh Shopee ditambah dengan rendahnya literasi pembeli dapat memicu adanya pengancaman kepada kurir karena pembeli yang kecewa dan tidak mengetahui prosedur pengembalian barang akan melampiaskan kekecewaan kepada kurir sebagai pihak yang ditemui langsung.

Tepat pada waktunya

Relevan

Lengkap
Dua informan memiliki persepsi bahwa Shopee telah memberikan ketepatan waktu terkait informasi tentang kedatangan kurir pengantar paket dengan metode pembayaran COD, sehingga informan dapat mempersiapkan uang tunai. Dua informan lainnya memiliki persepsi bahwa Shopee tidak akurat dalam memberikan informasi terkait kapan waktu kedatangan kurir, sehingga kurir datang pada saat informan tidak ada di rumah, sedang beristirahat atau informan sedang tidak memiliki uang tunai.

Satu informan mengemukakan persepsinya bahwa informasi yang disampaikan Shopee terkait metode pembayaran COD pada aplikasi sudah sangat relevan, sedangkan ketiga informan lainnya memiliki persespsi bahwa informasi yang disampaikan Shopee lebih banyak promosi dibanding informasi detail terkait metode pembayaran COD. Shopee lebih menginformasikan terkait bebas ongkir jika menggunakan metode pembayaran COD dibanding informasi tentang tata cara pengembalian barang dan keharusan membuat video unboxing agar dapat menjadi bukti ketika mengajukan pengembalian barang. Satu informan lainnya memberikan jawaban bahwa ia tidak terlalu memusingkan tentang informasi yang diberikan oleh Shopee karena ia memiliki persepsi bahwa aplikasi hanya mementingkan keuntungan untuk bisnisnya sehingga tidak mungkin aplikasi dapat memberikan informasi yang jujur terkait aturan dalam layanan yang disediakan, dalam hal ini layanan metode pembayaran COD. Informasi yang tidak relevan dapat saja membuat pembeli yang tidak mengetahui informasi secara jelas, akan meminta kurir untuk bertanggung jawab sebagai pihak yang terlihat dalam transaksi belanja online.

Tiga informan memiliki persepsi bahwa informasi yang diberikan Shopee melalui aplikasinya terkait metode pembayaran COD tidak lengkap. Shopee tidak memberikan informasi secara lengkap dan aktif dalam berupaya memberikan informasi. Penjelasan aturan metode pembayaran COD yang ada pada menu pusat bantuan menyulitkan pengguna Shopee yang tidak memiliki waktu untuk membuka seluruh menu Shopee ditambah beragamnya publik Shopee dari berbagai latar belakang pendidikan, seharusnya Shopee lebih membuat informasi pada tempat yang mudah ditemukan oleh berbagai pengguna aplikasi Shopee. Informasi yang tidak didapat dari Shopee melainkan dari pihak lain bisa saja informasi yang salah dan menimbulkan pemikiran bagi pembeli bahwa kurir jasa expedisi adalah penyebab tidak sesuainya barang yang diterima, sehingga Shopee seharusnya dapat menghadirkan informasi yang lebih lengkap dan mudah dijangkau untuk mendapatkan informasi tersebut. 


\section{Simpulan}

Jawaban atas pertanyaan penelitian pertama yaitu bagaimana persepsi pengguna e-commerce terhadap kualitas informasi yang diberikan Shopee terkait aturan dalam pembelian barang menggunakan metode pembayaran COD adalah tiga informan memiliki persepsi bahwa kualitas informasi yang disampaikan oleh Shopee melalui aplikasi terkait metode pembayaran COD meliputi aturan pembayaran, larangan membuka paket sebelum dibayar, prosedur pengembalian barang dinilai belum akurat, belum tepat waktu, belum relevan dan belum lengkap. Dua orang informan memiliki persepsi bahwa informasi yang dibagikan Shopee melalui aplikasi terkait pembelian barang melalui metode pembayaran COD lebih mengutamakan keuntungan bisnis dibanding mengedukasi pembeli tentang aturan yang berlaku dapat pembelian barang melalui metode pembayaran COD. Bagi satu informan, Shopee telah menyampaikan informasi yang akurat, relevan dan lengkap terkait pembelian barang menggunakan metode pembayaran COD, namun Shopee sebaiknya mengemas informasi terkait pembelian barang menggunakan metode pembayaran COD dengan memperhatikan bahwa publik yang dimiliki Shopee beragam, masih terdapat publik dalam hal ini pembeli yang memiliki pemahaman rendah dalam membaca sebuah informasi.

Pertanyaan kedua atas penelitian ini yaitu apakah persepsi tersebut dapat menimbulkan pengancaman kepada kurir jasa expedisi? Peneliti menemukan jawaban bahwa pembeli yang kecewa atas barang yang ia terima dan tidak mendapat informasi atau tidak mengetahui adanya informasi terkait proseur pengembalian barang, tidak diperkenankannya membuka paket sebelum melakukan pembayaran kepada kurir, adanya kesempatan untuk melakukan penolakan atas barang dengan syarat paket belum dibuka, dapat memicu pembeli melampiaskan kekecewaan atau amarahnya kepada kurir karena kurir jasa expedisi merupakan pihak yang ditemui secara langsung oleh pembeli. Informasi yang tidak didapat dari Shopee melainkan dari pihak lain bisa saja sebuah informasi yang salah dan menimbulkan pemikiran bagi pembeli bahwa kurir jasa expedisi merupakan pihak yang menyebabkan penyebab tidak sesuainya barang yang diterima dengan barang yang dipesan pembeli melalui aplikasi Shopee.

Informan dalam penelitian ini menyarankan agar Shopee membuat informasi terkait pembelian barang dengan metode pembayaran COD dalam bentuk visualisasi yang menarik, tidak dengan kalimat yang panjang sehingga mudah dimengerti. Informasi tersebut diletakkan pada menu tampilan yang mudah dilihat oleh pembeli seperti pada halaman layar utama atau informasi tersebut muncul ketika pembeli akan melakukan cek out atas barang dengan metode pembayaran COD tersebut. Menurut persepsi yang dimiliki informan dalam penelitian ini, hal tersebut dapat mencegah ketidakpahaman atau kebingungan pembeli yang berbelanja online melalui aplikasi Shopee dengan metode pembayaran COD sehingga pembeli yang kecewa terhadap paket yang diterima tidak melakukan pengancaman kepada kurir jasa expedisi, melainkan mengajukan pengembalian barang sesuai prosedur yang telah diinformasikan oleh Shopee.

\section{Referensi}

Babbie, Earl. 2012. The Basics of social Research 6th edition.Wadsworth Cengage Learning.

Hariyanto, Eri dan Desak Ketut. 2019. Komunikasi Publik di Era Industri 4.0:Pelajaran dari Strategi Pemerintah Mengkomunikasikan Utang Kepada Masyarakat.

Melbourne:@Jualinbukumu.

Jogiyanto. 2005. Analisis dan Desain Sistem Informasi. Yogyakarta : Andi. 
Mulyana, Deddy. 2006. Metode Penelitian Kualitatif. Bandung : PT.

Mulyana, Deddy. 2015. Ilmu Komunikasi. Bandung : PT Rosda Karya Offset.

O'Brien, James.A. 2005.Introduction to Information System. New York: McGraw-Hill.

Rakhmat, Jalaludin. 2005. Psikologi Komunikasi. Bandung : PT Remaja Rosda Karya Offset.

Susanto, Azhar. 2004. Sistem Inforasi Manajemen: Konsep pengembanganya. Bandung : Linggar Jaya.

Yusuf, Muri. 2014. Metode Penelitian Kuantitatif, Kualitatif, dan Penelitian Gabungan. Jakarta: Kencana.

https://money.kompas.com/read/2021/02/1 6/220300826/apa-itu-cod-dalam-jualbeli-online-simak-risiko-dankeuntungannya?page $=$ all

https://help.shopee.co.id/s/article/Bagaiman a-cara-melakukan-pembelianmenggunakan-COD-Cash-on-Delivery

https://id.techinasia.com/rasionalisasibisnis-di-balik-pembayaran-cod-yang$\underline{\text { rentan-masalah }}$

https://megapolitan.kompas.com/read/2021/ 05/26/19493801/pria-di-ciputat-ancamkurir-cod-dengan-pedang-karenamerasa-ditipu-beli

https://www.kompas.com/tren/read/2021/0 5/04/130500465/video-viral-kurirditodong-pistol-oleh-pelanggannya-initanggapan-ninja?page $=$ all

https://www.kompas.tv/article/174323/kurir -cod-kembali-dimaki-customer-ibu-initolak-bayar-paket-karena-tak-sesuaipesanan?page $=$ all

https://www.kompas.com/tren/read/2021/0 6/11/130000765/video-viral-kurirdimaki-dan-diguyur-air-konsumenylki-cod-dihapus-saja?page=all
https://help.shopee.co.id/s/article/Bagaiman a-cara-melakukan-pembelianmenggunakan-COD-Cash-on-Delivery. 